\title{
Causes and effects of delays in Malaysian construction industry
}

\begin{abstract}
The problem of delays in the construction industry is a global phenomenon and the construction industry in Malaysia is no exception. The main purpose of this study is to identify the delay factors and their impact (effect) on project completion. Earlier studies either considered the causes or the effects of project delays, separately. This study takes an integrated approach and attempts to analyze the impact of specific causes on specific effects. A questionnaire survey was conducted to solicit the causes and effects of delay from clients, consultants, and contractors. About 150 respondents participated in the survey. This study identified 10 most important causes of delay from a list of 28 different causes and 6 different effects of delay. Ten most important causes were: (1) contractorôs improper planning, (2) contractorôs poor site management, (3) inadequate contractor experience, (4) inadequate clientôs finance and payments for completed work, (5) problems with subcontractors, (6) shortage in material, (7) labor supply, (8) equipment availability and failure, (9) lack of communication between parties, and (10) mistakes during the construction stage. Six main effects of delay were: (1) time overrun, (2) cost overrun, (3) disputes, (4) arbitration, (5) litigation, and (6) total abandonment. This study has also established an empirical relationship between each cause and effect.
\end{abstract}

Keyword: Delay causes; Delay effects; Construction industry; Malaysia; Correlational analysis 